\title{
Labor as a welfare measure in contingent valuation: the value of a forest restoration project
}

\author{
Ignacio Schiappacasse ${ }^{1}$, Felipe Vásquez², Laura Nahuelhual ${ }^{3,5}$, and Cristian \\ Echeverría ${ }^{4}$ \\ ${ }^{1}$ Departamento de Economía, Facultad de Ciencias Económicas y Administrativas, Universidad de \\ Concepción, Casilla 160-C, Concepción, Chile. \\ ${ }^{2}$ Facultad de Economía y Negocios, Universidad del Desarrollo. Ainavillo 456, Concepción, Chile. \\ ${ }^{3}$ Instituto de Economía Agraria, Facultad de Ciencias Agrarias, Universidad Austral de Chile. \\ Independencia 641, Valdivia, Chile. \\ ${ }^{4}$ Facultad de Ciencias Forestales, Universidad de Concepción. Casilla 160-C, Concepción, Chile. \\ ${ }^{5}$ Fundación Centro de los Bosques Nativos FORECOS, Valdivia, Chile.
}

\begin{abstract}
I. Schiappacasse, F. Vásquez, L. Nahuelhual, and C. Echeverría. 2013. Labor as a welfare measure in contingent valuation: the value of a forest restoration project. Cien. Inv. Agr. 40(1):69-84. Monetary contributions might not be appropriate welfare measures in contingent valuation (CV) when household incomes are very low. In such cases, willingness to pay (WTP) is restricted by a household's ability to reduce its consumption of other goods to pay for the environmental good under valuation. Beneficiaries, however, may be willing to contribute their time to work on a project instead of paying money. In this context, we assess the benefits of ecosystem services restoration in a rural area of high conservation value in central Chile, using a CV study that includes two WTP questions, one for cash and another for labor payments. The results indicate that labor payments in the form of a number of working hours per week were highly accepted among people. In fact, in our sample, more people were willing to pay with labor time than with traditional cash payments. When we analyze the economic efficiency of the restoration project considering only cash payments, the net present value (NPV) is negative (-US\$255,834), but when we consider the value of time payments, the NPV is US $\$ 629,980$. The results indicate that this approach ought to be seriously considered in contingent valuation in similar social and economic contexts.
\end{abstract}

Key words: cost-benefit analysis; contingent valuation; ecosystem services; labor payments

\section{Introduction}

The non-market valuation literature has focused almost exclusively on the role of income constraints, largely ignoring the role of the time budget in

Received June 27, 2012. Accepted January 23, 2013. Corresponding author: 1schiappacasse@udec.cl demand (Smith, 1997). However, time, like income, is a scarce resource, and therefore is also a constraining factor in economic decisions (Bockstael et al., 1987). The values people place on environmental resources, therefore, are reflected in part by their time allocation. Hence, considering how time allocation is affected by the amount or quality of these resources provides us another 
basis for observing how a person's valuation of these resource features influences their behavior (Smith, 1997).

The contingent valuation (CV) method interprets a person's willingness to pay (WTP) for a commodity (e.g., environmental quality) as a monetary measure of the welfare she obtains from the consumption of that commodity (Haab and McConnell, 2003). However, WTP in terms of money might not be a good measure of people's welfare in cases where household incomes are very low (O'Garra, 2009), where a subsistence economy prevails (Hung et al., 2007; Saxena et al., 2008), or where there are imperfections in rural labor markets (Echessah et al., 1997; Kamuanga et al., 2001; Swallow and Woudyalew, 1994). In such cases, WTP is restricted by a household's ability to reduce its consumption of other goods to pay for the good offered in the hypothetical market created in the CV application (Ahlheilm et al., 2011). Potential buyers of a good in a market (or beneficiaries of a project outcome) may be willing to "pay time" instead of money, that is, they might be willing to assign part of their time to work in activities that ensure the provision of the environmental good being analyzed. CV applications have largely ignored this possibility, in part because a labor time contribution is not feasible in all applications of $\mathrm{CV}$ and in part because time constraints and income constraints are not collapsible into each other, due to lack of flexibility in the labor market (Bockstael et al., 1987). This issue becomes more significant in less developed countries where CV applications are less pervasive and imperfect labor markets are pervasive. Beyond these reasons, a consequence of not applying this methodology and lack of flexibility in the $\mathrm{CV}$ is an underestimation of the impact that changes in the environmental good have on people's welfare.

Using time (along with income) as a utility measure in $\mathrm{CV}$ poses some problems and challenges. First, it is necessary to place a monetary value on the number of hours declared by the respondents; second, it is necessary to find a theoretically consistent way to incorporate time in the model; and third, an appropriate econometric model must be selected to address two dependent variables, time and income. It is also essential to consider the impact that time elicitations could have when estimating the benefits associated with an increase in the natural capital.

Furthermore, the incorporation of time could be important in addressing ethical criticisms that have been raised concerning non-market valuation methods and in particular CV. These criticisms pertain to the fact that these methods are based on the construction of demand curves, which in turn are determined by preferences weighted by wealth and income (Rees et al., 2007). These approaches make the implicit (un) ethical assumption that an individual's "vote" on the value of non-market benefits - freely provided by natural capital - should be weighted by his success in the market economy (Rees et al., 2007). Thus, the incorporation of time elicitations into $\mathrm{CV}$ welfare estimations contributes to providing more flexibility to $\mathrm{CV}$ applications, validating the method in terms of its fairness and giving greater weight to the preferences of those with greater budget constraints (Farley and Brown, 2007).

Examination of the $\mathrm{CV}$ literature suggests that very few authors have used time contributions as a numeraire for welfare measures (e.g., Swallow and Woudyalew, 1994; Hung et al., 2007; O'Garra, 2009). Furthermore, the studies that do incorporate time contributions are based on evidence from Asia and Africa. This study represents a first attempt to assess the performance of $\mathrm{CV}$ in a rural setting in Latin America, eliciting WTP in terms of money and/or labor contributions. For this purpose, we include two $\mathrm{CV}$ questions in the valuation portion of the survey instrument: one for willingness to pay money (WTPM) and another for willingness to pay time (WTPT) in terms of labor payments. This approach permits the calculation of WTP as a measure of the benefits of dryland forest restoration in central Chile. The specific objectives of this study are (i) to analyze 
the acceptance of contingent payments in terms of labor and/or money, (ii) to evaluate the factors that influence the form in which the potential beneficiaries of the proposed restoration project state their willingness to pay, (iii) to estimate the net benefits arising from the restoration project, and (iv) to assess the possible substitution or complementary effects among the two forms of payment.

\section{Material and methods}

\section{Case study of forest restoration}

This work was developed in the context of the international collaborative research project "Restoration of Dryland Forests in Latin America" (REFORLAN, http://reforlan.bournemouth.ac.uk/), which is focused on the restoration of dryland forest landscapes for biodiversity conservation and rural development in Latin America (Newton, 2008). The project was developed as a response to widespread ecological degradation of dryland areas of Latin America (Newton, 2008).

The study was conducted in the Colliguay Valley $\left(33^{\circ} 07^{\prime}-33^{\circ} 14^{\prime} \mathrm{S}\right.$ and $71^{\circ} 15^{\prime}-71^{\circ} 00^{\prime} \mathrm{W}$, Figure 1$)$, which is located in the semiarid portion of the Mediterranean bioclimatic zone of central Chile (Luebert and Pliscoff, 2006; UNESCO, 2010). Due to its great biodiversity, high degree of endemism, and critical conservation status, this region is one of the world's 34 biodiversity hotspots (Mittermeier et al., 2005). The region is home to approximately 2400 plant species, $23 \%$ of which are endemic (Cowling et al., 1996). Despite the rarity and global importance of Chile's Mediterranean ecosystems, less than $0.8 \%$ of them are currently protected (Lara et al., 2010). In fact, despite the Valley having been declared a protected area by the Chilean Ministry of Agriculture in 1974 and a Priority Site for Biodiversity Conservation in 2002 (CONAMA and PNUD, 2005), at present, the Colliguay Valley's forests are not under any type of legal protection.
The Valley is located in the coastal range of the Valparaíso administrative region and covers 27,000 ha. According to Luebert and Pliscoff (2006), the Valley is located within the distribution of the sclerophyllous forest formation of the Mediterranean zone in central Chile (Figure 1). Because of the limited accessibility of the Valley and the presence of steep slopes, the study area contains an outstanding biodiversity of dryland ecosystems that have been preserved over the last several decades (Borde and Góngora, 1956; Zunino et al., 2007). However, the biodiversity in the Valley has been affected - as has the biodiversity in all of central Chile - by human disturbances such as intense forest logging for fuel wood and clear cutting for agricultural expansion (Camus and Hayek, 1998). These human-induced changes have resulted in a spatially heterogeneous mosaic of vegetation, including some xerophytic plant species. At present, the Valley contains dryland forest at different successional stages.

\section{Research design}

Questionnaire description. Following Loomis et al. (2000), we used CV to assess the total benefits that landowners obtain from restoring dryland forest ecosystem services in central Chile. Despite the fact that these ecosystem services are often not assigned monetary values, they affect the welfare of individuals, and therefore, changes in these services may have potentially significant effects on real income (Loomis et al., 2000). There are other possible methods of measuring the aggregate WTP for ecosystem services provided by restored forests (e.g., the production function approach), but the use of CV is supported by the fact that management actions considered in the restoration program will affect the provision of a set of services, with both use and non-use values (Loomis et al., 2000). Generally, when ecosystem services are highly correlated in production, $\mathrm{CV}$ is a more appropriate approach (Bonnieux and Le Goffe, 1997; Holmes et al., 2004). 


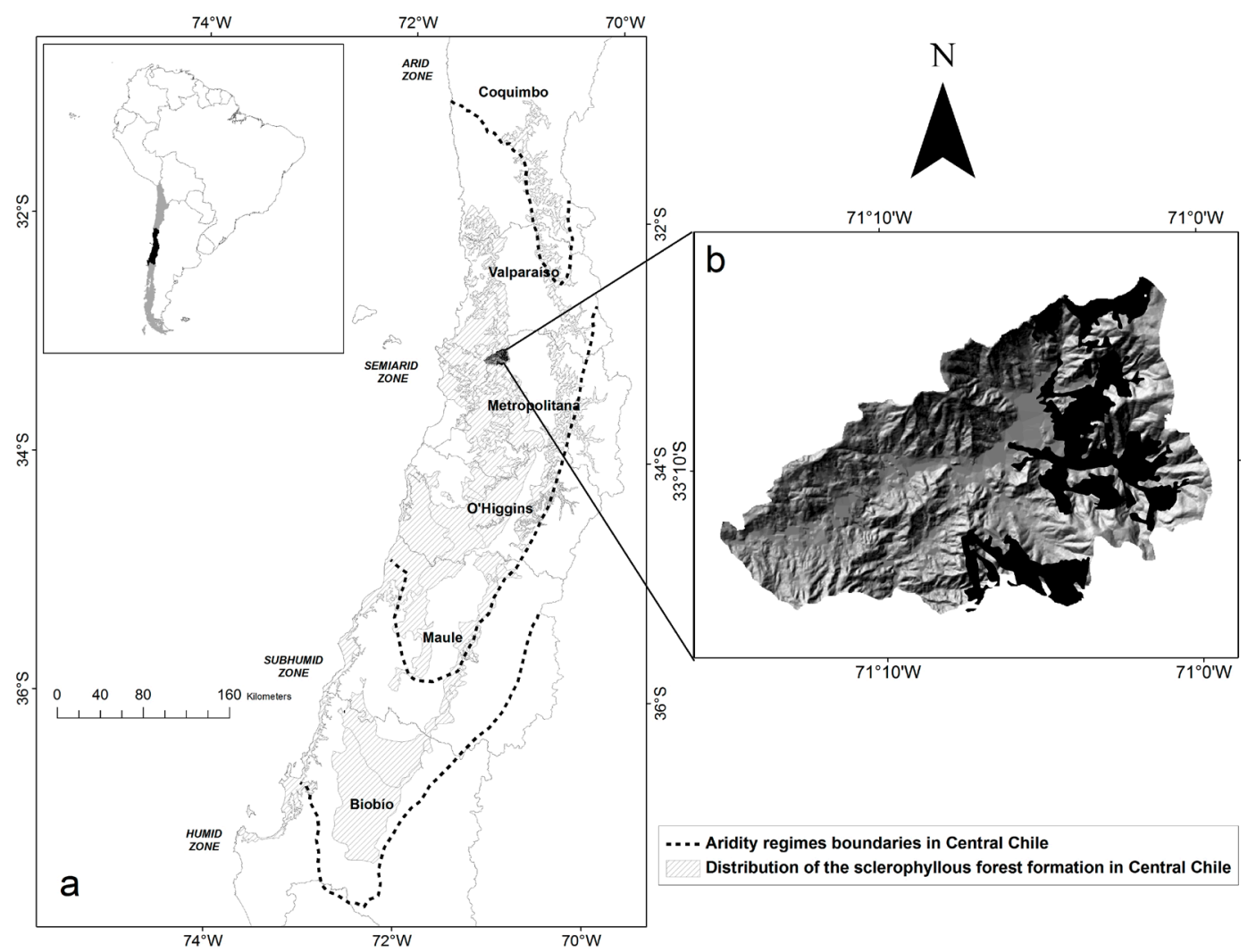

Figure 1. Index maps. (a) Location of the study area in the Valparaíso administrative region in central Chile; (b) Map of the Colliguay Valley depicting (in black) the area corresponding to the Priority Site for Biodiversity Conservation.

Because values elicited via CV are contingent upon the information and market context described in the CV instrument (MacMillan and Duff, 1998; Zhongmin et al., 2003), considerable effort was expended in developing a questionnaire that would allow respondents to formulate a value for the active restoration program. In January 2008, a workshop was held in the Colliguay Valley to bring together over 30 people, including local landowners and public officials. On this occasion, a preliminary survey was applied and a discussion was conducted regarding dryland forest restoration. The final survey was then designed and pre-tested to reveal any misinterpretation of the questions or ambiguity in response categories. As the majority of both private and public benefits stemming from restoration are gained by local communities (Bonnieux and Le Goffe, 1997), we assumed that visitors' benefits represent a small portion of the value of the restoration. Hence, the study focused only on the local population. Thus, the final household survey was applied through in-depth in-person interviews, conducted in February 2008, of members of a random sample of households. Fifty-eight percent of the families living in the area (92 completed interviews) were surveyed.

The first section of the survey gathered personal information about the interviewee (e.g., age, income). The second section asked about the household's productive characteristics (e.g., land tenure, forest area, farming area). The third section was devoted to forest use practices. Finally, the last section included the CV questions that permitted the calculation of WTP as a measure of the benefits of restoring the degraded forest in the Valley. This part was composed of (i) portrayal of the problem 
(i.e., widespread degradation of the Valley's forests) and its possible consequences, (ii) description and characterization of the proposed solution (active ecological restoration of the forest), (iii) characterization of the active restoration program, (iv) expected outcomes of the program, and (v) the questions used to elicit the respondent's true value for the restoration program.

The respondents were given a list of the key ecosystem services that the forest provides to local people, which are (i) control of soil erosion and reduction of sediment accumulation in the Valley's streams, (ii) water regulation for better freshwater provisioning during the summer, (iii) nectar from native species for honey production, (iv) recreation and tourism opportunities, and (v) provision of non-timber forest products (e.g., medicinal plants). The means by which ecosystem services could be restored from their current status were also described.

In the valuation portion of the survey, the respondents were first asked whether they would participate in a project of forest restoration such as the one described in the first section. Then, the interviewers stated that the respondents could contribute labor, money or both to the restoration project. Next, open-ended questions were posed to elicit the maximum amount of labor (in terms of hours per week) and money that the respondents would be willing to contribute to the restoration project. In the case of monetary contributions, the payment mechanism proposed in the valuation scenario was a monthly payment made to the local rural water committee. In the case of labor contributions, the mechanism was hours of weekly work dedicated to the implementation of the project (by planting, fencing, etc). Thus, first we asked: "If a forest restoration project such as that previously described were carried out, would you participate?" If the answer was negative, we followed up with an inquiry about the reasons for not participating. If the answer was positive, we followed up by asking the maximum number of hours per week that the interviewee would be willing to contribute to the project and the maximum amount of money that the interviewee would be willing to contribute monthly to the implementation of the project.

Due to the low number of families in the Valley (159 households) and budget constraints, we interviewed only 92 families (58\% of the population). This is a small sample for a discrete choice model; therefore, we opted for the open-ended (OE) elicitation question format instead of the theoretically preferred closed-ended (CE) elicitation format. The OE format requires fewer responses to achieve a given variance about the mean WTP, compared to a CE dichotomous-choice CV (Haab and McConnell, 2003). Unfortunately, the OE questions are not theoretically incentive compatible (they may lead to extreme responses) and are believed to yield an unusually high percentage of $\$ 0$ responses (Boyle, 2003). We asked a series of follow-up questions after the WTP question to determine whether negative responses (refusals) were a valid representation of the respondents' true values or reflected a protest of some features of the simulated market (Carson et al., 2003). Ten responses (10.8\%) were classified as protest responses and therefore were dropped from the sample. This protest ratio is similar to others reported in the CV literature (e.g., $18 \%$ in Strazzera et al., 2003; 6\% in Zhongmin et al., 2003). We consider the elicitation format to be a secondary issue for the purposes of this analysis because we are interested in showing the effect of ignoring time contributions in the estimation of value, and we think this should not be significantly affected by the elicitation format.

Econometric specification. As each respondent was asked about the maximum number of hours per week that he or she would be willing to contribute (WTPT) and the maximum amount of money that he or she would be willing to pay (WTPM), the answers to these two questions generate four response patterns: (i) both values are zero (WTPT $=0$, and $\mathrm{WTPM}=0$ ), (ii) time contributions are positive but money contributions are zero (WTPT $>0$, WTPM=0), (iii) money 
contributions are positive but time contributions are zero (WTPT $=0$, WTPM $>0$ ), or (iv) both are positive (WTPT $>0$,WTPM $>0$ ). Therefore, one important issue that exists in this analysis is the possible interdependence that exists across these two sorts of expenditures (i.e., WTPM and WTPT). Assuming no interdependence and applying univariate Tobit models, which take into account the presence of censoring at zero (Amemiya, 1984), to each dependent variable separately may produce biased estimates (Hsiao, 1986). Thus, we investigated the interrelationship of the two expenditure types using a bivariate Tobit setting (e.g., Cornick et al., 1994; Huang, 1999). The two equations estimated are as follows:

$y_{i t}^{*}=\beta_{1}{ }^{\prime} x_{i t}+u_{i t} \quad i=1,2$

$y_{i t}=y_{i t}^{*}$ if $y_{i t}^{*}>0 \quad i=1,2$

$y_{i t}=0$ otherwise $\quad i=1,2$

where $\mathrm{i}=1$ for money contributions, $\mathrm{i}=2$ for time contributions, and $t=1,2, \ldots, N$ denotes individuals. Therefore $y_{1 t}^{*}$ is the latent variable of WTPT, $y_{2 t}$ is the latent variable of WTPM, $x_{l t}$ is a vector of explanatory variables that explains $y_{l t}, x_{2 t}$ is a vector of explanatory variables that explains $y_{2 t}$ ,and $u_{1 t}$ and $u_{2 t}$ are error terms. The model was developed in the context of the joint distribution of $\left(y_{1 t}^{*}, y_{2 t}^{*}\right)$ assuming a bivariate normal distribution $B V N\left(\gamma_{1} y_{2 t}+\beta_{1}^{\prime} x_{1 t}, \gamma_{2} y_{l t}+\beta_{2}^{\prime} x_{2 t}, \sigma_{1}^{2}, \sigma_{2}^{2}, \rho\right)$, where $\sigma_{1}, \sigma_{2}$ and $\rho$ are the standard deviations of the marginal distribution of $y_{1 t}^{*}$ and $y_{2 t}^{*}$, and the correlation coefficient of $y_{1 t}^{*}$ and $y_{2 t}^{*}$, respectively. The likelihood function of the joint outcomes in the sample can be specified as follows:

$$
\begin{gathered}
L=\prod_{\left\{i \mid y_{l i}>0, y_{2 i}>0\right\}} f\left(y_{1 t}-\beta_{1}^{\prime} x_{1 t}, y_{2 t}-\beta_{2}^{\prime} x_{2 t}\right) \\
\prod_{\left\{i \mid y_{l i}>0, y_{2 i}=0\right\}} \int_{-\infty}^{-\beta_{2}^{\prime} x_{2 t}} f\left(y_{1 t}-\beta_{I}^{\prime} x_{1 t}, u_{2}\right) d u_{2} \\
\prod_{\left\{i \mid y_{l i}=0, y_{2 i}>0\right\}} \int_{-\infty}^{-\beta_{l}^{\prime} x_{l t}} f\left(u_{1}, y_{2 t}-\beta_{2}^{\prime} x_{2 t}\right) d u_{1}
\end{gathered}
$$

$\prod_{\left\{i \mid y_{1 i}=0, y_{2 i}=0\right\}} \int_{-\infty}^{-\beta_{2}^{\prime} x_{2 t}} \int_{-\infty}^{-\beta_{1}^{\prime} x_{1 t}} f\left(u_{1}, u_{2}\right) d u_{1} d u_{2}$

A maximum-likelihood estimation was carried out with the Stata module to perform bivariate Tobit regression (Lawson, 2007). If $\rho$ were indeed zero, the joint normal density function would collapse to the product of two independent normal density functions, and a univariate approach of separately estimated equations would be appropriate (Yoo, 2005).

Both the univariate and bivariate Tobit models were estimated for comparison. In the former, the model restricts the off-diagonal covariance matrix terms to be zero (Yoo, 2005). In the bivariate model, the interdependence of WTPT and WTPM is tested by applying the $z$ test. This test uses the fact that the correlation coefficient, $\rho$, between the error terms in the two expenditure equations is constrained to be zero when a univariate model is used.

Imputing monetary value to labor contributions. If one wants to use these results to conduct a cost-benefit analysis, it is necessary to overcome the problem of how to place a monetary value on the number of hours declared by the interviewee. In the non-market valuation literature (Cesario, 1976; Bockstael et al., 1987; O'Garra, 2009), the common approach is to establish an ad hoc rule for the opportunity cost of time. This opportunity cost depends on socioeconomic characteristics (age, sex, etc.) and labor market characteristics.

In the latter case, we need to distinguish between those individuals who can choose their working time freely from those individuals who are unable to choose the number of hours they work. Following Bockstael et al. (1987) for individuals in the first group, we used the wage rate as the opportunity cost of time because people can arbitrarily exchange working time and leisure time. For individuals in the second group, we followed a conservative approach and calculate the opportunity cost of time as a portion (a third) 
of the wage rate, as suggested by Cesario (1976). Thus, in this respect, we rely on the consensus of the non-market valuation literature (fundamentally the literature related with the travel cost method), and we apply it in contingent valuation.

\section{Data description}

Table 1 contains definitions, sample statistics and expected signs of selected household characteristics and other variables used as covariates in the univariate and bivariate Tobit models.

Approximately $68 \%$ of the people interviewed were older than 46, and a similar percentage (65.2\%) had lived all their lives in Colliguay Valley. Only approximately $2 \%$ of the respondents were less than 25 years old. Half of the respondents had completed only elementary education (up to eight years of formal education in Chile); $8 \%$ did not have any formal education. The monthly income of the surveyed households ranged from US\$ 239 to US\$ 431 and was derived mainly from offfarm labor activities (38.9\%), and subsidies and pensions (29.4\%). The agrosilvipastoral activities with the highest contribution to family income were cattle raising (10\%) and selling of forest products $(6.7 \%)$. According to the Family Budget
Survey (INE, 2008), the majority of the families in the Valley are within the first and second quintiles of the national income distribution (i.e., the poorest ranges). The average farm size was 9.5 ha, ranging from 0.05 to 200 ha; $76 \%$ of the surveyed households had land parcels smaller than 5 ha, with the most frequent farm size being one ha. Household land tenure is fragmented and holdings undergo constant division because of demographic pressure and inheritance practices.

\section{Results and discussion}

Response rates and acceptance of contingent payments in terms of labor

Our first analysis compared the proportions of households that would pay some positive amount of money and contribute a positive amount of labor, to test for significant differences between the mean estimates. The results indicate a broad acceptance of the labor payment vehicle. In fact, $14.6 \%$ (12 of 82 ) of the households were willing to pay only through labor, and none of the households were willing to pay only money. These proportions were significantly different at the 1 percent level (Chi-square=12.95). Furthermore, $81.7 \%$ (67 of 82 ) of the households were willing

Table 1. Variable description and sample statistics.

\begin{tabular}{llrr}
\hline Variable & Description & Mean & Standard Deviation \\
\hline WTPM $^{1}$ & Monthly willingness to pay for the restoration project (US\$) & 4.97 & 8.39 \\
WTPT $^{2}$ & Monthly willingness to give time to the restoration program $^{1}$ & 24.0 & 22.3 \\
INCOME $^{1}$ & Monthly household income (US\$) & 353.8 & 224.45 \\
HOUR & $\begin{array}{l}\text { Total number of available hours per month after work, personal activities and } \\
\text { domestic duties }\end{array}$ & 121.95 & 30.1 \\
VISION & $\begin{array}{l}\text { Binary variable equal to 1 if the respondent thinks forests can be sustainably } \\
\text { exploited and 0 otherwise }\end{array}$ & 0.18 & 0.39 \\
LAND & $\begin{array}{l}\text { Total farm area } \\
\text { VISION_2 }\end{array}$ & $\begin{array}{l}\text { Binary variable equal to 1 if the respondent thinks forests are an important } \\
\text { symbol of the valley and 0 otherwise }\end{array}$ & 0.68 \\
AGE & Age of the respondent & 52.9 & 0.43 \\
\hline
\end{tabular}

${ }^{1}$ Chilean pesos were transformed to US dollars using the 2008 exchange rate of CP \$522 to US \$1; the sample size for estimation was 82 .

${ }^{2}$ For modeling purposes the variable WTPT was converted from hours per week to hours per month. 
to pay money and labor, and only $3.7 \%$ (3 of 82 ) of the households were not willing to pay either money or labor.

The level of declared contributions was also high, particularly the level of labor payments. Labor contributions ranged from zero to $100 \mathrm{~h}$ per month, and money payments ranged from zero to US\$ 57 per month. The 67 households that were willing to pay both money and labor indicated an average willingness to pay of US\$6.08 $( \pm 8.92$ $\mathrm{SD})$ and $26.9 \mathrm{~h}( \pm 23.11 \mathrm{SD})$, while the households that were willing to pay only labor indicated an average willingness to pay labor of $13.0 \mathrm{~h}( \pm 10.5$ $\mathrm{SD}$ ). The analysis of variance indicates that those who were willing to pay labor and money offered significantly higher amounts of labor than those willing to pay only labor $(\mathrm{P} \leq 0.05)$.

These results imply that more people would be willing to pay through contributions of labor time than through traditional cash payments. This finding is consistent with findings reported in the majority of the CV studies that have considered payments in terms of labor time. For instance, Kamuanga et al. (2001), in the context of a pastoral economy in West Africa, Swallow and Woudyalew (1994), and Echessah et al. (1997) in East Africa, Hung et al. (2007) in Vietnam, and Biro (1998) in Turkey reported that more households were willing to contribute labor than money for various public goods and in various contexts.

Finally, and following Orme (2005), we estimated confidence intervals and the margin of error of the data. On the one hand, if we consider that the aim is to estimate the proportion of individuals who are willing to pay money and/or time (WTPM and WTPT), we find that $96 \%$ of the respondents show this response pattern (WTPM $>0$ and $\mathrm{WTPT}>0$ ). This implies that the margin of error is close to $3 \%$. On the other hand, if we consider the proportion of those who are willing to pay both money and time, the margin of error is $5.8 \%$, implying that the $95 \%$ confidence interval is $(0.758,0.875)$. Considering, then, that we have two continuous variables, WTPM and WTPT, their margins of error are 2.3 and 0.97 , respectively. This yields $96 \%$ confidence intervals of $(21,26)$ for WTPT and $(4.09,5.84)$ for WTPM. Overall, this means that despite the small sample size, the confidence intervals are reasonably bounded and do not include zero.

\section{Modeling results}

The estimation results for the univariate and bivariate models obtained using the maximum likelihood method are presented in Table 2. The $z$ score for the estimate of $\rho$ in Table 2 (2.55) exceeds the critical value at the $5 \%$ level, so the null hypothesis of $\rho=0$ can be rejected. It is clear from the $z$ test result that the data should be analyzed in a bivariate setting. In addition, the statistical significance of the bivariate model was examined using the Wald test. The test statistic was calculated to be 26.50 , which is large enough to reject, at the $1 \%$ level, the null hypothesis that all slope coefficients are zero, indicating the overall significance of the model.

The income coefficient (INCOME) was positive for both WTPM and WTPT but statistically significant only for WTPM (at the 1\% level). On the other hand, the time constraint (HOUR), which is the number of hours available for activities other than work, was positive and significant at the $1 \%$ level only in the case of WTPT. The coefficient of HOUR suggests that more monthly available hours would increase WTPT for restoration.

In the case of WTPM, the variables VISION and LAND were positive and significant at the 5\% level, indicating that WTPM increases with all the observed variables (Table 2). The fact that respondents with higher incomes are willing to pay more supports the notion that ecosystem services are normal goods (Cho et al., 2008). Regarding the variable LAND, respondents that hold larger farms were found to be likely to pay more for a restoration program as they feel they have a 
Table 2. Estimation results for the univariate and bivariate models.

\begin{tabular}{|c|c|c|c|c|}
\hline \multirow[b]{2}{*}{ Variables } & \multicolumn{2}{|c|}{ Univariate model } & \multicolumn{2}{|c|}{ Bivariate model } \\
\hline & WTPT & WTPM & WTPT & WTPM \\
\hline CONSTANT & $\begin{array}{r}0.970 \\
(0.07)\end{array}$ & $\begin{array}{l}-4.605 \\
(-0.99)\end{array}$ & $\begin{array}{l}-0.940 \\
(-0.07)\end{array}$ & $\begin{array}{l}-5.819 \\
(-1.24)\end{array}$ \\
\hline INCOME & $\begin{array}{l}0.010 \\
(1.02)\end{array}$ & $\begin{array}{r}0.011 \\
(2.63)^{* * *}\end{array}$ & $\begin{array}{l}0.010 \\
(1.02)\end{array}$ & $\begin{array}{r}0.013 \\
(2.90)^{* * *}\end{array}$ \\
\hline HOUR & $\begin{array}{r}0.266 \\
(3.57)^{* * *}\end{array}$ & $\begin{array}{r}0.016 \\
(0.47)\end{array}$ & $\begin{array}{r}0.263 \\
(3.51)^{* * *}\end{array}$ & $\begin{array}{l}0.026 \\
(0.77)\end{array}$ \\
\hline VISION_2 & $\begin{array}{r}14.342 \\
(3.18)^{* * *}\end{array}$ & --- & $\begin{array}{r}12.232 \\
(2.80)^{* * *}\end{array}$ & --- \\
\hline AGE & $\begin{array}{r}-0.369 \\
(-2.22)^{* *}\end{array}$ & --- & $\begin{array}{l}-0.308 \\
(-1.94)^{*}\end{array}$ & -- \\
\hline VISION & --- & $\begin{array}{r}6.074 \\
(2.53)^{* *}\end{array}$ & --- & $\begin{array}{r}5.800 \\
(2.54)^{* *}\end{array}$ \\
\hline LAND & --- & $\begin{array}{r}0.229 \\
(3.38)^{* * *}\end{array}$ & --- & $\begin{array}{r}0.159 \\
(2.32)^{* * *}\end{array}$ \\
\hline$\rho$ & 0 & 0 & & $\begin{array}{r}0.593 \\
(2.55)^{* *}\end{array}$ \\
\hline$\sigma_{1}$ & $\begin{array}{r}19.19642 \\
(12.479)^{* * *}\end{array}$ & --- & & $\begin{array}{r}19.288 \\
(12.38)^{* * *}\end{array}$ \\
\hline$\sigma_{2}$ & --- & $\begin{array}{r}7.898 \\
(11.337)^{* * *}\end{array}$ & & $\begin{array}{r}7.955 \\
(11.24)^{* * *}\end{array}$ \\
\hline Log-likelihood & -348.726 & -245.588 & & -590.273 \\
\hline Sample size & 82 & 82 & & 82 \\
\hline
\end{tabular}

Notes: $t$-values are reported in parentheses below the estimates. *,**, and *** indicate statistical significance at the 10,5 , and $1 \%$ levels, respectively.

higher chance of receiving the project's benefits. Thus, for WTPT, the coefficient of VISION_2 was positive and statistically significant at the $1 \%$ level, suggesting that when forest is thought to be an important community symbol, WTPT is affected positively. The coefficient of AGE was negative and statistically significant at the 5\% level, implying that willingness to contribute time to the restoration project decreases with age. This finding was consistent with prior expectations: older people would be less likely to agree to pay time for restoration because of their life expectancy (restoration benefits accrue over a long period of time) and because of physical conditions that may hinder their ability to contribute labor to the project.
The large coefficient of VISION for WTPM and VISION_2 for WTPT, relative to the effects of other variables, is an important finding for policy making. Public trusts, nongovernmental organizations (NGOs), and governments should be aware that education programs that raise the level of public knowledge about the importance of restoration may be useful in increasing public acceptance and financial support for restoration initiatives (Cho et al., 2008). Currently, Latin American countries exhibit a precarious inclusion of environmental education in school curriculums, and these partial efforts are burdened by shortages due to low governmental investment in the sector (Gónzalez-Gaudiano, 2007). In this context, environmental education is a critical tool for engaging the public and increasing financial support for restoration initiatives (Potter, 2010). 


\section{Aggregating and comparing benefits}

The mean monthly household WTPM was found to be US\$ 4.97. This implies that each household would be willing to pay an average of US\$ 59.6 per year for the restoration project. Multiplying the mean annual WTP by the Valley's population, the annual aggregate benefit of restoring forest ecosystem services in Colliguay is US\$ 9,536. Considering the length of the proposed project (25 years) and using the social discount rate established by the Chilean Ministry of Planning and Cooperation $(6.2 \%)$, the present value of restoring dryland forest in Colliguay, considering only WTPM, is estimated to be US\$127,036.

The mean monthly household WTPT is 23.95 h. From the sample, 61 respondents declared that they freely chose their work time (case i). Thus, the value of time used in this case is the average wage rate for a farm laborer in central Chile, which is US\$ 15.3 per day. The mean monthly household WTPT for this group is 25.0 $\mathrm{h}$ per month. Thus, the mean opportunity cost of time that respondents are willing to pay for the restoration project is US\$ 47.9 per month. On the other hand, 31 respondents had fixed work times (case ii), so for these individuals we assumed that they would trade off leisure time to spend time restoring forest ecosystem services. For this group, the mean monthly household WTPT is $22.2 \mathrm{~h}$. Considering an opportunity cost of time of one third of the wage rate, the mean monetary value of these time elicitations is US\$ 12.8 per month. In consequence, the average monthly willingness to pay time for the restoration project in Colliguay is US\$ 34.6, implying that each household would pay an average of US\$ 415.6 per year for the restoration project. Multiplying this mean annual WTPT by the Valley's population, the annual benefits of restoring forest ecosystem services in Colliguay estimated from the WTPT elicitations is US\$ 66,494. Therefore, the present value of dryland forest restoration, considering only WTPT, is estimated to be US\$ 885,814 .
Both, WTPM and WTPT reflect a significant value for restoration. For instance, in the case of WTPT, the amount of time the respondents would be willing to pay for the restoration project represents $18 \%$ of the total amount of time that respondents have available for leisure and other activities (their time restriction in the econometric model; the variable HOUR). On the other hand, the annual WTPM per household also reflects a high value for restoration: the mean WTPM represents $1.4 \%$ of the total respondent's mean income. These results are consistent with the responses to other sections of the questionnaire. Most households (94\%) considered the forest an asset that they have to protect. Likewise, a substantial proportion of the interviewees (41\%) acknowledged forests as important community symbols. Most respondents said that they were interested in participating in restoration initiatives $(90 \%)$. Overall, it seems that the respondents feel strongly that they have a responsibility to protect forest resources.

Adding the benefits estimated in terms of WTPM and WTPT, the aggregate present value of restoring dryland forest in Colliguay is estimated to be US\$ $1,012,850$. This value is almost ten times greater than if we only consider the willingness to pay money in the calculation of the benefits generated by the proposed restoration project. The combination of WTPM and WTPT in the calculation of the aggregate benefits is rationalized by the fact that each respondent was given the options to pay money and/or labor, generating four types of responses: (i) to pay nothing, (ii) to pay only money, (iii) to pay only labor, or (iv) to pay both money and labor. As mentioned before, this last option was chosen by the majority of respondents, indicating that they effectively stated one part of their "total" willingness to pay in terms of money and another part in terms of labor. The addition of time and labor payments is also supported by the complementary association observed between WTPT and WTPM. 


\section{Substitution and complementary effects}

Contrary to our expectations, respondents tend not to substitute money for or with labor. We hypothesized that households with lower disposable incomes would be willing to pay in terms of time rather than money; that is, the income constraint (INCOME) should have had a negative effect on WTPT. However, the results do not show a statistically significant relationship between WTPT and INCOME (Table 2).

The complementary association between labor and money payments is supported by the aforementioned fact that respondents who were willing to pay in terms of both money and labor offered higher amounts of labor than those willing to pay only by labor. In addition, univariate Tobit analyses were run with WTPT as a dependent variable and WTPM as an explanatory variable and vice versa. These Tobit results (not shown) indicate a strong positive and significant relationship between willingness to pay time and willingness to pay money. The same is observed in the reciprocal relation. These results are similar to those obtained in other CV studies (e.g., Kamuanga et al., 2001) in which a complementary association between contributions in terms of money and labor have been observed.

Thus, we have evidence that may not support our hypothesis that people of low income living in the Valley would prefer labor rather than cash payments. On the one hand, income did not influence WTPT, but on the other hand, more people would be willing to pay time than money, possibly indicating that people have many cash demands and few opportunities for earning money. This antagonism could be explained by the complementary association of WTPT and WTPM: when an individual has a significant commitment to forest restoration and/or he/she understands its importance to ecosystem services provision, he/she will be willing to pay a higher sum of money for forest restoration and at the same time be willing to give more time to the program. Therefore, payments in terms of labor could effectively be providing a more flexible framework for respondents to state their "true" value for the restoration project, which would be underestimated if only cash payments were allowed.

\section{Policy and methodological implications}

The issue of considering labor-time elicitations for the estimation of welfare measures in $\mathrm{CV}$ is central to environmental management. Decision makers often request a cost-benefit analysis as part of their deliberations, and $\mathrm{CV}$ is increasingly being used to measure the economic benefits of environmental outcomes of projects (Rees et al., 2007). In this context, a project is worth investing in if the benefits outweigh the costs over the life of the proposed project. Thus, if we do not take time payments into account in the estimation of welfare measures, we could underestimate the benefits estimated when applying $\mathrm{CV}$, causing the rejection of projects that would otherwise be socially desirable. For instance, in the case of the restoration project proposed for the Colliguay Valley as part of the REFORLAN project, the total present value of costs is calculated to be US\$ 382,870 . If we only consider cash payments, the net present value (NPV) of the project is negative (-US\$ 255,834), and it may not be economically feasible. However, considering the value of time contributions, the NPV is US\$ 629,980 . In this case, the project meets the economic efficiency criteria because the economic benefits are greater than the restoration costs. Therefore, depending on which approach we use, completely different results may be obtained, which will influence the decision process about the execution of a particular project.

Time payment vehicles are potentially very useful not only in the context of low-income economies but also in settings where the goods or services to be valued require some participation from the intended beneficiaries. CV is increasingly being 
applied to value projects and programs whose effectiveness depends upon the cooperation and participation of local residents and the performance of local organizations. For instance, this is the case of tsetse control in Africa, where control targets are a local public good that generates benefits for anyone who keeps livestock in the area covered by the targets (Swallow and Woudyalew, 1994; Echessah et al., 1997; Kamuanga et al., 2001). This is also the case of forest restoration, in which success will depend on factors controlled by local people, such as protection of plants from livestock (Lamb and Gilmour, 2003). In such settings, local involvement is critical for successful interventions. As individuals are often asked to make contributions in terms of labor for such projects, CV surveys that address payments in terms of labor often seem more plausible than those that address cash payments only.

This methodological approach, however, requires further development and presents several issues. For example, overestimation of WTP money is a common phenomenon in CV studies. Therefore, it is highly likely that some respondents gave overestimates of their willingness to pay time due to strategic bias. In particular, in our study case, the mean WTPT was $23.9 \mathrm{~h}$ per month, which is three "labor" days (for an 8-hour workday) devoted to the restoration project. Due to the requirements of daily living, this may not be feasible in the context of the surveyed households. We hypothesize that this overestimation could be related to three possible sources of bias: (i) lack of clarity in relation to the time constraint; (ii) warm glow; and (iii) the open-ended elicitation format, which is not incentive compatible.

First, compared with the budget constraint, the time constraint might be more difficult to for the respondent to perceive and consider. Therefore, in future studies, respondents should be reminded more carefully about their time constraint, adding specific didactic examples for the particular context in which the CV will be applied. Second, the overestimation of WTPT could also be related to warm glow. Warm glow in this context is defined as an increase in utility resulting from the act of giving in addition to the utility generated by the increase in the total supply of the public good (Champ et al., 1997). One clear option to circumvent this problem is to apply a method of correcting for hypothetical bias (Champ et al., 2001). This method has been applied in the context of contingent donations, but it could be very useful in this context because donation payment mechanisms are essentially based on an open-ended format. Basically, this approach consists of formulating follow-up questions in which respondents rate their level of certainty about their response to the $\mathrm{CV}$ question. This has proven to be a successful technique (Champ et al., 1997; Champ et al., 2001). Finally, part of the findings might be explained by the selection of the open-ended format, which is not fully demand-revealing because it allows for the possibility of free riding (i.e., its lack of incentive compatibility).

This last issue is an important challenge in this novel approach to non-market valuation. In fact, the incentive compatibility of time elicitation questions has not yet been discussed in the literature. As we noted, using an additional payment method (other than money) is an issue of great interest, in particular in developing countries (Whittington, 2010). It is, however, also a great challenge due to the difficulty of asking an incentivecompatible valuation question to elicit WTP for the benefits, especially when asking about WTP in terms of time. Therefore, the challenge is how to ask valuation questions while preventing the occurrence of strategic biases. This type of bias occurs when a respondent gives a WTP amount that differs from his or her true WTP amount in an attempt to influence the provision of the good and/or the respondent's level of payment for the good (Mitchell and Carson, 1989). The consensus in the CV literature is that when using money as the numeraire for WTP, there is no such problem if a binary discrete-choice referendum format with a take-it-or-leave-it question that is resistant 
to strategic bias is used; that is, truth-telling is the individually optimal strategy (Mitchell and Carson 1989; for formal proof, see Hoehn and Randall 1987). This is explained by the fact that the payment vehicle clearly establishes how much other people are paying for the good being valued (for example, a tax bill would be related to a household's income), and it is easy to ask the question in a way that would make the respondent internalize that the payment is mandatory. However, in the case of time elicitations, the problem arises from the fact that in most settings, it is not at all realistic to propose mandatory time contributions. Therefore, in the case of time elicitations, it may not be enough to ask valuation questions using the binary dichotomous-choice format to claim that the valuation questions are incentive compatible (Carson and Groves, 2007).
Future studies should also focus on developing a conceptual framework for eliciting labor payment willingness in an incentive-compatible way. The estimation of WTPT and WTPM within a utility-consistent structure would provide much more robust estimations. This is a natural next step in this research area, which would validate the approach and yield reliable results.

\section{Acknowledgments}

This work was undertaken as part of the REFORLAN Project, supported by the European Commission INCO Programme (INCO-DEV-3 $\mathrm{N}^{\circ}$ 032132). The authors also gratefully thank the support of the Latin American and Caribbean Environmental Economics Program (LACEEP) for the achievement of this research work.

\section{Resumen}

I. Schiappacasse, F. Vásquez, L. Nahuelhual y C. Echeverría. 2013. Horas de trabajo como medida de bienestar en valoración contingente. El valor de un proyecto de restauración forestal. Cien. Inv. Agr. 40(1):69-84. En el contexto de Valoración Contingente (VC), las contribuciones monetarias pueden no ser una medida de bienestar adecuada cuando el ingreso de las familias es bajo. En tales casos, la disposición a pagar (DAP) está restringida por la posibilidad de que la familia reduzca el consumo de otros bienes con el objeto de pagar por el bien o servicio ambiental que se está evaluando. Los beneficiarios de un proyecto ambiental podrían, sin embargo, estar dispuestos a contribuir con tiempo de trabajo en lugar de pagar con dinero. Considerando lo anterior, en el presente estudio valoramos los beneficios generados a partir de la restauración de los servicios ecosistémicos en un paisaje rural de alto valor de conservación ubicado en Chile central. Para ello aplicamos un estudio de VC que incluye dos preguntas de DAP: una para pagos en efectivo y otra para pagos en términos de trabajo. Los resultados indican que los pagos con tiempo de trabajo (i.e. "horas de trabajo a la semana") fueron ampliamente aceptados. En efecto, en nuestra muestra hubo más gente dispuesta a pagar en términos de tiempo de trabajo que por medio de los pagos tradicionales con dinero en efectivo. Si sólo consideramos los pagos en efectivo para analizar la eficiencia del proyecto de restauración, el Valor Presente Neto (VPN) del proyecto es negativo (-US\$255,834). En contraste, cuando consideramos el valor de los pagos en términos de tiempo, el VPN es US $\$ 629,980$. En general, estos resultados respaldan el hecho de que este enfoque debería ser seriamente considerado al diseñar escenarios de $\mathrm{VC}$ en contextos económicos y sociales similares.

Palabras clave: Análisis costo-beneficio, valoración contingente, servicios ecosistémicos pagos con tiempo de trabajo 


\section{References}

Amemiya, T. 1984. Tobit models: A survey. Journal of Econometrics 24: 3-61.

Biro, Y. 1998. Valuing the environmental impacts of the Kayraktepe Dam/hydroelectric project, Turkey: an exercise in contingent valuation. Ambio 27: 224-229.

Bockstael N., I. Strand, and M. Hanemann. 1987. Time and the Recreational Demand Model. American Journal of Agricultural Economics 69: 293-302.

Bonnieux F., and P. Le Goffe. 1997. Valuing the benefits of Landscape Restoration: A Case Study of the Cotentin in Lower-Normandy, France. Journal of Environmental Management 50: 321-333.

Borde, J., and M. Gongora. 1956. Evolución de la Propiedad Rural en el Valle del Puangue. Editorial Universitaria, Santiago, Chile. 251 pp.

Boyle, K. 2003. Contingent Valuation in Practice. In: P. Champ, K. Boyle and T. Brown (eds.). A Primer on Nonmarket Valuation. p. 111-169. Kluwer Academic Publishers, The Netherlands. 592 pp.

Camus, P., and E. Hajek. 1998. Historia Ambiental de Chile. Andros Impresores, Santiago, Chile. 181 pp.

Carson, R., and T. Groves. 2007. Incentive and informational properties of preference questions. Environmental and Resource Economics 37:181-210.

Carson, R., R. Mitchell, M. Hanemann, R.J. Kopp, S. Presser, and P.A. Ruud. 2003. Contingent valuation and lost passive use: Damages from the Exxon Valdez oil spill. Environmental and Resource Economics 25: 257-286.

Cesario, F. 1976. Value of time in recreation benefit studies. Land Economics 52:32-41.

Champ P., and R.C. Bishop. 2001. Donation payment mechanisms and contingent valuation: An empirical study of hypothetical bias. Environmental and Resource Economics 19:383-402.

Champ P, R.C. Bishop, T.C. Brown, and D.W. McCollum. 1997. Using Donation Mechanisms to Value Nonuse Benefits from Public Goods. Journal of Environmental Economics and Management 33:151-162.
Cho S.-H., S.T. Yen, J.M. Bowker, and D.H. Newman. 2008. Modelling willingness to pay for land conservation easements: Treatments of zero and protest bids and application and policy implications. Journal of Agricultural and Applied Economics 40: 267-285.

CONAMA-PNUD. 2005. Estrategia y Plan de acción para la Conservación de la diversidad biológica, región de Valparaíso. Comisión Nacional del Medio Ambiente (CONAMA), Gobierno de Chile - Programa de las Naciones Unidas para el Desarrollo (PNUD). Available online at: http:/ www.mma.gob.cl (Website accessed: May 8, 2011).

Cornick, J., T.L. Cox, and B.W. Gould. 1994. Fluid milk purchases: a multivariate Tobit analysis. American Journal of Agricultural Economics 76:74-82.

Cowling, R.M., P.W. Rundel, B.B. Lamont, M.K. Arroyo, and M. Arianoutsou. 1996. Plant diversity in Mediterranean-climate regions. Trends in Ecology and Evolution 11: 362-366.

Echessah, P.N., B. M. Swallow, D.W. Kamara, and J.J. Curry. 1997. Willingness to contribute labor and money to tsetse control: Application of contingent valuation in Busia District, Kenya. World Development 25: 239-253.

Farley, J., and E.J. Brown. 2007. Restoring Natural Capital: An Ecological Economics Assessment. In: J. Aronson, S.J. Milton, and J.N. Blignaut (eds.). Restoring natural capital: Science, Business, and Practice. p. 17-27. Island Press, USA. 400 pp.

Haab, T.C., and K.E. McConnell. 2003. Valuing Environmental and Natural Resources: The Econometrics of Non-Market Valuation. Edward Elgar, England. 256 pp.

Holmes, T.P., J.C. Bergstrom, E. Huszar, S.B. Kask, and F. Orr III. 2004. Contingent valuation, net marginal benefits, and the scale of riparian ecosystem restoration. Ecological Economics 49:19-30.

Hoehn, J. and A. Randall. 1987. A satisfactory benefit cost indicator from contingent valuation. Journal of Environmental Economics and Management $14: 226-247$. 
Hsiao, C. 1986. Analysis of Panel Data. Cambridge University Press, England. 384 pp.

Huang, H. 1999. Estimation of the SUR Tobit model via the MCECM algorithm. Economics Letters 64: $25-30$.

Hung, L.T., J.B. Loomis, and V.T. Thinh. 2007. Comparing money and labour payment in contingent valuation: the case of forest fire prevention in Vietnamese context. Journal of International Development 19:173-185.

INE. 2008. Población y Sociedad: Aspectos Demográficos 1950-2004. Departamento de Estadísticas Demográficas y Vitales, Instituto Nacional de Estadísticas (INE). Gobierno de Chile. Santiago, Chile.

Kamuanga, M., B.M. Swallow, H. Sigue, and B. Bauer. 2001. Evaluating contingent and actual contributions to a local public good: Tsetse control in the Yale agro-pastoral zone, Burkina Faso. Ecological Economics 39:115-130.

Lamb, D., and D. Gilmour. 2003. Rehabilitation and restoration of degraded forests. IUCN, Gland, Switzerland and Cambridge, UK and WWF, Gland, Switzerland. 110 pp.

Lara, A., R. Reyes, and R. Urrutia. 2010. Bosques Nativos. In: Centro de Análisis de Políticas Públicas, Universidad de Chile (ed.). Informe País: Estado del Medio Ambiente en Chile 2008. p. 126171. Instituto de Asuntos Públicos, Universidad de Chile, Chile. 508 pp.

Lawson, D. 2007. Stata module to perform bivariate Tobit regression. Available online at: http://ideas. repec.org/c/boc/bocode/s456864.html (Website accessed: January 20, 2011).

Loomis, J., P. Kent, L. Strange, F. Kurt, and A. Covich. 2000. Measuring the total economic value of restoring ecosystem services in an impaired river basin: results from a contingent valuation survey. Ecological Economics 33:103-117.

Luebert, F., and P. Pliscoff. 2006. Sinopsis Bioclimática y Vegetacional de Chile. Editorial Universitaria, Santiago, Chile. 318 pp.

MacMillan, D.C., and E.I. Duff. 1998. Estimating the non-market costs and benefits of native woodland restoration using the contingent valuation method. Forestry 71:247-259.
Mitchell, R., and R. Carson. 1989. Using Surveys to Value Public Goods: The Contingent Valuation Method. Resources for the Future, Washington DC, USA. 484 pp.

Mittermeier, R., P. Gil, M. Hoffman, J. Pilgrim, T. Brooks, C. Mittermeier, J. Lamoreux, and G. Da Fonseca. 2005. Hotspots Revisited: Earth`s Biologically Richest and Most Endangered Terrestrial Ecoregions. Cemex, Conservation International and Agrupación Sierra Madre. Mexico. 392 pp.

Newton, A. 2008. Restoration of dryland forests in Latin America: The ReForLan Project. Ecological Restoration 26:10-11.

O'Garra, T. 2009. Bequest Values for Marine Resources: How Important for Indigenous Communities in Less-Developed Economies? Environmental and Resource Economics 44:179-202.

Orme, B. 2005. Getting started with conjoint analysis: strategies product design and pricing research. Research Publisher, LLC. USA. 179 pp.

Potter, G. 2010. Environmental Education for the 21st Century: Where do we go now? The Journal of Environmental Education 41:22-33.

Rees, W.E., J. Farley, E.T. Vesely, and R. de Groot. 2007. Valuing natural capital and the costs and benefits of restoration. In: J. Aronson, S.J. Milton, and J.N. Blignaut (eds.). Restoring natural capital: Science, Business, and Practice. p. 227-236. Island Press, USA. 400 pp.

Saxena, A.K., N.S. Bisht, and C.J. Singh. 2008. The value of the Indian gazelle (Gazella gazella): A case study in Haryana, India. Indian Forester 134:1289-1295.

Smith, K. 1997. Time and the valuation of environmental resources. Discussion Paper 9807. Resource for the Future, USA. 29 pp.

Strazzera, E., M. Genius, R. Scarpa, and G. Hutchinson G. 2003. The effect of protest votes on the estimates of WTP for use values of recreational sites. Environmental and Resource Economics 25:461-476.

Swallow, B.M., and M. Woudyalew. 1994. Evaluating willingness to contribute to a local public good: Application of contingent valuation to tsetse 
control in Ethiopia. Ecological Economics 11:153-161.

UNESCO. 2010. Atlas de Zonas Áridas de América Latina y El Caribe. International Hydrologic Program, UNESCO, Technical Document $\mathrm{N}^{\circ} 25$. UNESCO. Montevideo, Uruguay.

Whittington, D. 2010. What have we learned from 20 years of stated preference research in lessdeveloped countries? Annul Review of Resource Economics 2:209-236.

Yoo, S.-H. 2005. Analysing household bottled water and water purifier expenditures: simultaneous equation bivariate Tobit model. Applied Economics Letters 12:297-301.
Zhongmin, X., C. Guodong, Z. Zhiqiang, S. Zhiyong, and J. Loomis. 2003. Applying contingent valuation in China to measure the total economic value of restoring ecosystem services in Ejina region. Ecological Economics 44:345-358.

Zunino, S., J. Arancibia, D. Zunino, and J. Valencia. 2007. Estudio Biótico de la Sub-cuenca del Estero Puangue y Proposiciones para el Desarrollo Sustentable para la Localidad de Colliguay. Final report project FPA-05-011-07. Comisión Nacional del Medio Ambiente. Valparaíso, Chile. 